\title{
Two new genera and four new species of fossil weevils (Coleoptera: Curculionoidea) in Baltic amber
}

\author{
Andrei A. Legalov
}

Legalov, A. A. 2016: Two new genera and four new species of fossil weevils (Coleoptera: Curculionoidea) in Baltic amber. - Entomol. Fennica 27: 57-69.

Two new genera, Palaeodexipeus gen. n. (type species: Palaeodexipeus kirejtshuki sp. n.) and Succinalophus gen. n. (type species: S. attenboroughi sp. n.), and four new species, Oxycraspedus poinari sp. n., Palaeodexipeus kirejtshuki sp. n., Dorytomus electrinus sp. n. and Succinalophus attenboroughi sp. n., are described and illustrated. These are the first records of the tribes Oxycraspedini in the family Belidae, and Stromboscerini and Tropiphorini in Curculionidae in the Baltic amber.

A. A. Legalov, Institute of Systematics and Ecology of Animals, Siberian Branch, Russian Academy of Sciences, Frunze Street, 11, Novosibirsk 630091, Russia; E-mail:fossilweevils@gmail.com

Received 25 September 2015, accepted 28 October 2015

\section{Introduction}

Curculioinoid beetles are well represented in the fossil record (Bouchard et al. 2011, Legalov 2015), probably as a result of their solid integument and ability of many groups to fly. Fossil representatives of wingless extant weevils are also known primarily from amber. The oldest weevils are discovered in layers of the middle-late Jurassic of Karatau, and they represent 57 species from 3 families (Gratshev \& Legalov 2011, Legalov 2011, 2013b, Gratshev \& Legalov 2014). The number of the fossil specimens and described species rapidly increases thanks to current studies, and especially in the period between the early Cretaceous and the Neogene (Legalov 2012d). The superfamily Curculionoidea is the major group of Coleoptera represented in the Cenozoic sedimentary deposit that exhibits extraordinary fossils with exceptional preservation such as Green River and Florissant beds in USA, Aix-enProvance in France and Rott and Oeningen in
Germany, as well as in the Baltic and Dominican amber (Legalov 2015).

In this paper, two new genera and four new species from the Baltic amber are described.

\section{Materials and methods}

The Baltic amber mines are located along the Baltic Sea coast at the Amber quarry of Yantarny near Kaliningrad in the Kaliningrad Oblast (Russia). The amber from this deposit was probably produced by the tree pine Pinus succinifera (Goeppert) Conwentz (Schubert 1961). The Baltic amber from this Prussian Formation dates back to the upper Eocene (Grigjalis et al. 1971), although sometimes it is considered older, even the Lowermost Eocene (Weitschat \& Wichard 2010).

The type specimens are stored in the Institute of Systematics and Ecology of Animals, the Siberian Branch of the Russian Academy of Sciences 
(Novosibirsk, Russia). Comparative material is deposited in the Institute of Systematics and Ecology of Animals, Museum für Tierkunde, Senckenberg Naturhistorischen Sammlungen Dresden (Germany) and the Zoological Institute of the Russian Academy of Sciences.

Descriptions and photographs were taken using the Zeiss Stemi 2000-C dissecting stereomicroscope.

The systematics of the studied taxa are given by Legalov $(2009,2015)$ and Gratshev and Legalov (2014) with corrections by Zherikhin and Egorov (1991), Kuschel (1995a) and Anderson (2002). The terminology of the names of body parts were used here after Klimaszewski and Watt (1997) and Anderson (2002) with some corrections.

\section{Systematics}

\subsection{Description of Oxycraspedus poinari sp. n.}

Belidae Schoenherr, 1826

Oxycoryninae Schoenherr, 1840

Oxycraspedini Marvaldi \& Oberprieler, 2006

Oxycraspedus Kuschel, 1955

Oxycraspedus poinari sp. n. (Fig. 1)

Type material. Holotype: no. BA2015/2, female.

Diagnosis. This new species is similar to $O$. cribricollis (Blanchard, 1851) from Chile and Argentina (Ferrer et al. 2007, Legalov 2009) but differs in the protibiae without a fringe of long setae, a body black, a more convex form and wider pronotum and elytra.

Description. Female. Body length (without rostrum) $3.7 \mathrm{~mm}$; rostrum length $1.1 \mathrm{~mm}$.

Body black, naked, partially appearing silvery shiny due to the presence of cavities between specimen and internal surface of its impression.

Head. Head 0.4 times as long as rostrum; rostrum long, narrow, almost equal in length to pronotum, 5.2 times longer than wide at apex and in middle, 3.4 times longer than wide at base, weakly convex, finely and densely punctate; forehead wide, 1.2 times as wide as rostrum base width, flattened, densely punctate, without median striae, without tubercles on either side; eyes large, rounded, convex, 1.1 times longer than wide; vertex weakly flattened, punctate; temples short, 0.8 times as long as eye, punctate; antennae inserted at base of rostrum ventrally, nongeniculate, quite long, reaching first third of pronotum; scape quite long, 2.4 times longer than wide; desmomeres almost conical; $1^{\text {st }}$ desmomere 1.6 times longer than wide, 0.6 times as long and 0.9 times as wide as scape; $2^{\text {nd }}$ desmomere 2.2 times longer than wide, 1.2 times as long and 0.8 times as wide as $1^{\text {st }}$ desmomere; $3^{\text {rd }}$ desmomere 1.8 times longer than wide, 0.7 times as long and 0.9 times as wide as $2^{\text {nd }}$ desmomere; $4^{\text {th }}$ desmomere equal to $3^{\text {rd }}$ desmomere; $5^{\text {th }}$ desmomere 1.4 times longer than wide, 0.9 times as long and 1.1 times as wide as $4^{\text {th }}$ desmomere; $6^{\text {th }}$ desmomere equal to $5^{\text {th }}$ desmomere; $7^{\text {th }}$ desmomere 1.3 times longer than wide, 1.1 times as long and 1.2 times as wide as $6^{\text {th }}$ desmomere; club noncompact, 0.6 times as long as flagellum; $1^{\text {st }}$ club article 1.3 times longer than wide, 1.1 times as long and 1.2 times as wide as $7^{\text {th }}$ desmomere; $2^{\text {nd }}$ and $3^{\text {rd }}$ club articles fused, 2.1 times longer than wide, 2.6 times as long and 1.6 times as wide as $1^{\text {st }}$ club article, weakly acuminate.

Pronotum. Pronotum transverse, 1.4 times longer than apical width, 0.9 times longer than wide in middle and at base; disk narrowed at apex and at base, densely and quite coarsely punctate.

Mesonotum. Scutellum small, rectangular.

Elytra. Elytra weakly convex, slightly elongate, 2.3 times as long as pronotum, 1.6 times longer than wide at base, 1.4 times longer than wide in middle, 2.1 times longer than wide in apical quarter; greatest width behind middle; humeri flattened; punctured striae quite regular and distinct; scutellar striole present; punctures rounded, dense; intervals somewhat flat, narrow, slightly wider than punctures; epipleuron distinct.

Thorax. Prosternum punctate, with lateral serrulate carina; precoxal part of prosternum weakly elongate, 1.2 times as long as procoxa length; procoxal cavities round, separated; postcoxal part of prosternum short, 0.5 times as long as procoxa length; mesocoxal cavities rounded, separated; metasternum short, 1.9 times as long as metacoxa length, convex, punctate; metepisternum narrow, densely punctate.

Abdomen. Abdomen weakly convex; ventrites free; $1^{\text {st }}$ ventrite 1.2 times as long as 

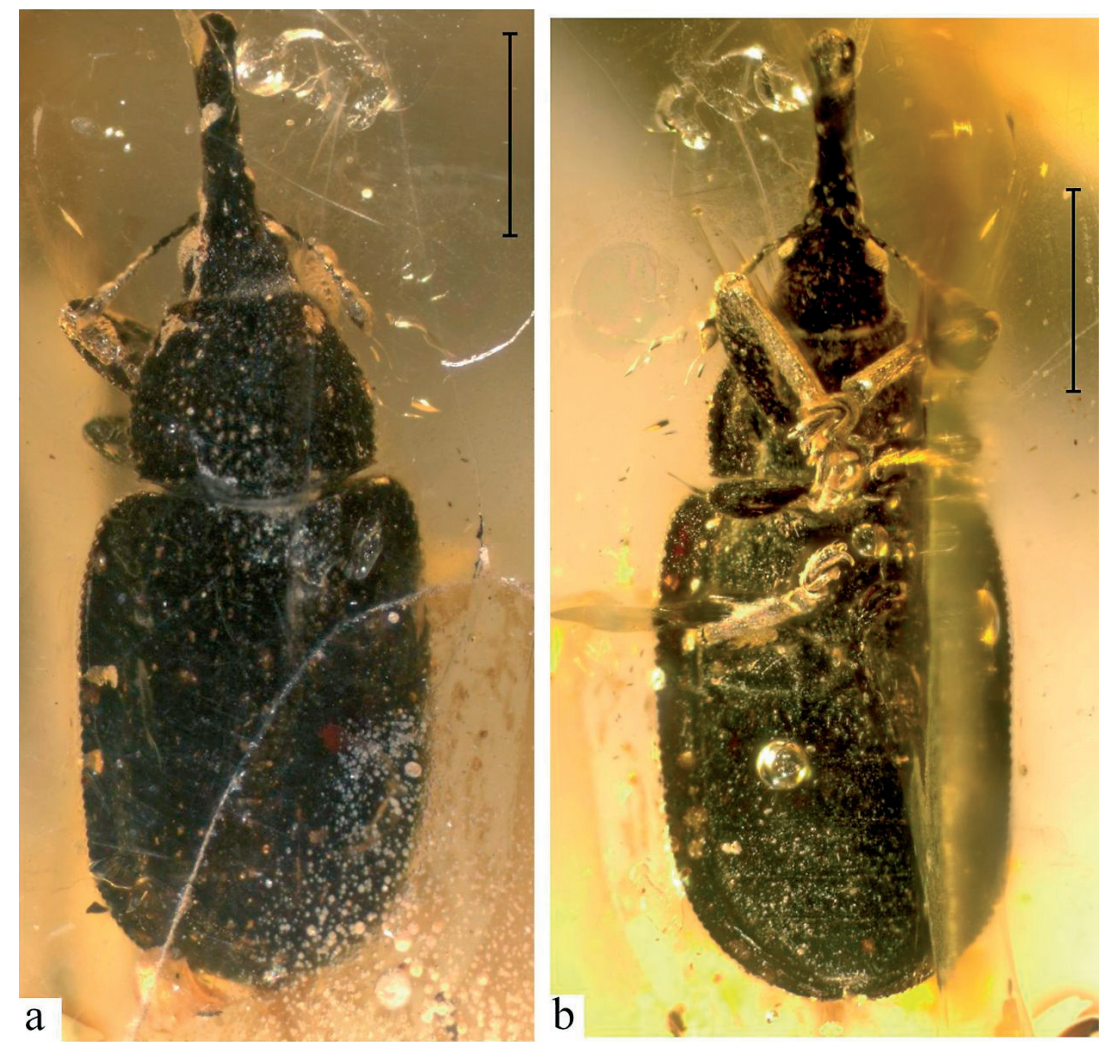

Fig. 1. Habitus of Oxycraspedus poinari sp. n. (holotype). - a. Dorsal view. - b. Ventral view. - c. Lateral (right) view. Scale bar $=1 \mathrm{~mm}$.

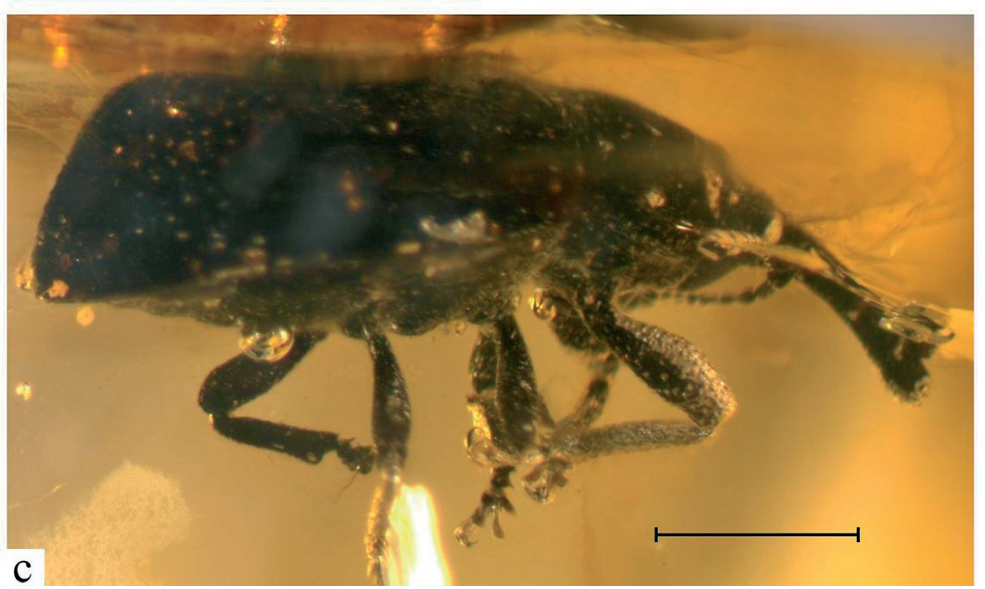

metacoxal length; $2^{\text {nd }}$ ventrite 0.9 times as long as $1^{\text {st }}$ ventrite; $3^{\text {rd }}$ ventrite 0.9 times as long as $2^{\text {nd }}$ ventrite; $4^{\text {th }}$ ventrite 0.7 times as long as $3^{\text {rd }}$ ventrite; $5^{\text {th }}$ ventrite 1.5 times as long as $4^{\text {th }}$ ventrite.

Legs. Legs long; femora weakly clavate and flattened, without teeth; profemur length/width ratio 2.9; mesofemur length/width ratio 2.9; metafemur length/width ratio 2.8 ; trochanter con- ical; tibiae almost straight, weakly flattened, widened at apices, with costate dorsal margin, with weak apical setose fringe, without mucro; protibiae possessing a wide apical groove clothed in fine, dense vestiture on the inner face opposite the tarsal articulation, without fringe of long setae, length/width ratio 5.1 ; mesotibia length/ width ratio 4.0 ; metatibia length/width ratio 5.1 ; tarsi long, with thick light erect setae dorsally; $1^{\text {st }}$ 
tarsomere triangular, shorter than the second and third tarsomeres combined; $2^{\text {nd }}$ and $3^{\text {rd }}$ tarsomeres widely bilobed; $5^{\text {th }}$ tarsomere elongate; claws large, connected, without teeth; protarsi: $1^{\text {st }}$ tarsomere 0.8 times longer than wide; $2^{\text {nd }}$ tarsomere 0.6 times longer than wide, 1.6 times as long as and 2.0 times as wide as $1^{\text {st }}$ tarsomere; $3^{\text {rd }}$ tarsomere 1.1 times longer than wide, 2.1 times as long as and 1.1 times as wide as $2^{\text {nd }}$ tarsomere; $5^{\text {th }}$ tarsomere 3.6 times longer than wide, 1.1 times as long as and 0.3 times as wide as $3^{\text {rd }}$ tarsomere; mesotarsi: $1^{\text {st }}$ tarsomere 0.7 times longer than wide; $2^{\text {nd }}$ tarsomere 0.7 times longer than wide, 1.8 times as long and 1.9 times as wide as $1^{\text {st }}$ tarsomere; $3^{\text {rd }}$ tarsomere 0.9 times longer than wide, 1.6 times as long and 1.2 times as wide as $2^{\text {nd }}$ tarsomere; $5^{\text {th }}$ tarsomere 2.7 times longer than wide, 1.1 times as long and 0.4 times as wide as $3^{\text {rd }}$ tarsomere; metatarsi: $1^{\text {st }}$ tarsomere 0.8 times longer than wide; $2^{\text {nd }}$ tarsomere 0.8 times longer than wide, 1.8 times as long and 2.0 times as wide as $1^{\text {st }}$ tarsomere; $3^{\text {rd }}$ tarsomere 1.1 times longer than wide, 1.6 times as long and 1.1 times as wide as $2^{\text {nd }}$ tarsomere; $5^{\text {th }}$ tarsomere 2.5 times longer than wide, 1.1 times as long and 0.5 times as wide as $3^{\text {rd }}$ tarsomere.

Type locality and type strata. Amber mines located along the Baltic Sea coast and Yantarny Amber quarry near Kaliningrad, Kaliningrad region, Russia, upper Eocene, Prussian Formation.

Etymology. The name is dedicated to my dear colleague, Dr. George O. Poinar, Jr. (Corvallis, USA), who has made a great contribution to the study of amber fauna.

Remarks. The new species belongs to the family Belidae based on the protibiae possessing a wide apical groove clothed in fine, dense vestiture on the inner face opposite the tarsal articulation, the first to fifth ventrites free and nongeniculate antennae. The transverse and bilobed second tarsomere, antennae inserted at the base of the rostrum, the distinct club, first tarsomere shorter than the second and third tarsomeres combined, suggest placement in the subfamily Oxycoryninae. The separated procoxal cavities suggest that the new species belongs to the monotypical tribe Oxycraspedini with the genus Oxycraspedus.

\subsection{Description of Palaeodexipeus gen. $\mathrm{n}$. and a new species}

Curculionidae Latreille, 1802

Dryophthorinae Schoenherr, 1825

Stromboscerini Lacordaire, 1866

\section{Palaeodexipeus gen. $\boldsymbol{n}$.}

Type species: Palaeodexipeus kirejtshuki sp. n.

Diagnosis. This new genus is similar to the genus Dexipeus Pascoe, 1885 from Japan, Java and Sumatra (Alonso-Zarazaga \& Lyal 1999) but differs by the unusual carinate elytral intervals, antennal club weakly obliquely truncate and the rostrum not widened at the antennal attachment. From the Oriental genus Orthosinus Motschulsky, 1863 and the genus Stenommatomorphus Nazarenko, 2009 from Eocene Rovno amber it differs by the eye being much wider than high and the carinate elytral intervals. The obliquely truncate antennal club of the new genus separates it from the Oriental genus Nephius Pascoe, 1885 and the genus Tasactes Faust, 1894 from Myanmar (Alonso-Zarazaga \& Lyal 1999) that have an antennal club with a subconical apex. The new genus is clearly distinguished from other genera of Stromboscerini (Besuchetiella Osella, 1974, Dryophthoroides Roelofs, 1879, Parasynommatus Voss, 1956, Stromboscerus Schoenherr, 1838, Synommatoides Morimoto, 1978, Synommatus Wollaston, 1873, Tetrasynommatus Morimoto, 1985) by the antennae with a 6-articled flagellum.

Etymology. The name is formed from the Greek " $\alpha \rho \chi \alpha 1 \alpha$ " (ancient) and the generic name Dexipeus.

Palaeodexipeus kirejtshuki gen. n. et sp. n. (Figs. 2-3)

Type material. Holotype: no. BA2015/3, male.

Description. Male. Body length (without rostrum) $3.1 \mathrm{~mm}$; rostrum length $0.7 \mathrm{~mm}$.

Body black, naked, appearing silvery shiny due to the presence of cavities between specimen and internal surface of its impression.

Head. Head 0.4 times as long as rostrum; mouthparts with prementum withdrawn into oral cavity; rostrum long, quite narrow, 3.2 times longer than width at apex, 3.3 times longer than width in middle, 3.0 times longer than width at 


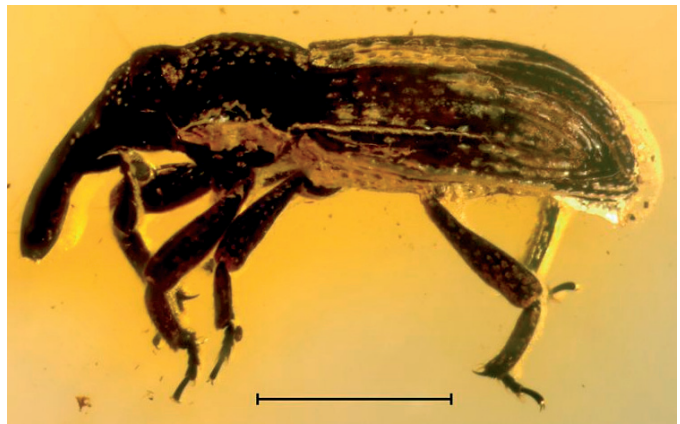

Fig. 2. Lateral (left) view of Palaeodexipeus kirejtshuki sp. $\mathbf{n}$. (holotype). Scale bar $=1 \mathrm{~mm}$.

base, 0.9 times as long as pronotum, weakly curved, finely punctate; antennal scrobes distinct; forehead narrow, 0.8 times as wide as rostrum base width, flattened, punctate, without median striae; eyes quite small, flat, 0.6 times longer than wide, separated ventrally; vertex weakly flattened, sparsely punctate; temples quite long, 1.7 times as long as eye, punctate; antennae inserted in first third of rostrum ventrally, geniculate, quite short, reaching first third of pronotum; scape 3.3 times longer than wide; flagellum with 6 wideconical desmomeres; $1^{\text {st }}$ desmomere 1.1 times longer than wide, 0.3 times as long and 0.8 times as wide as scape; $2^{\text {nd }}$ desmomere 0.8 times longer than wide, 0.7 times as long and equal in width to $1^{\text {st }}$ desmomere; $3^{\text {rd }}$ desmomere 0.4 times longer than wide, 0.6 times as long and equal in width to $2^{\text {nd }}$ desmomere; $4^{\text {th }}$ desmomere 0.4 times longer than wide, equal in length and 1.1. times as wide as $3^{\text {rd }}$ desmomere; $5^{\text {th }}$ desmomere equal to $4^{\text {th }}$ desmomere; $6^{\text {th }}$ desmomere 0.3 times longer than wide, equal in length and 1.2 times as wide as $5^{\text {th }}$ desmomere; club compact and asymmetrical, with elongated $1^{\text {st }}$ article and fused remaining articles, 1.3 times longer than wide, almost equal to funicle, weakly obliquely truncate, with tomentose apical surface flat.

Pronotum. Pronotum 1.5 times longer than apical width, 1.2 times longer than width in middle and 1.1 longer than width at base; disk weakly narrowed at apex and at base, densely punctate.

Mesonotum. Scutellum small, narrow, triangular.

Elytra. Elytra convex, elongate, 2.1 times as long as pronotum, 1.7 times longer than width at base, 1.5 times longer than wide in middle, 2.3

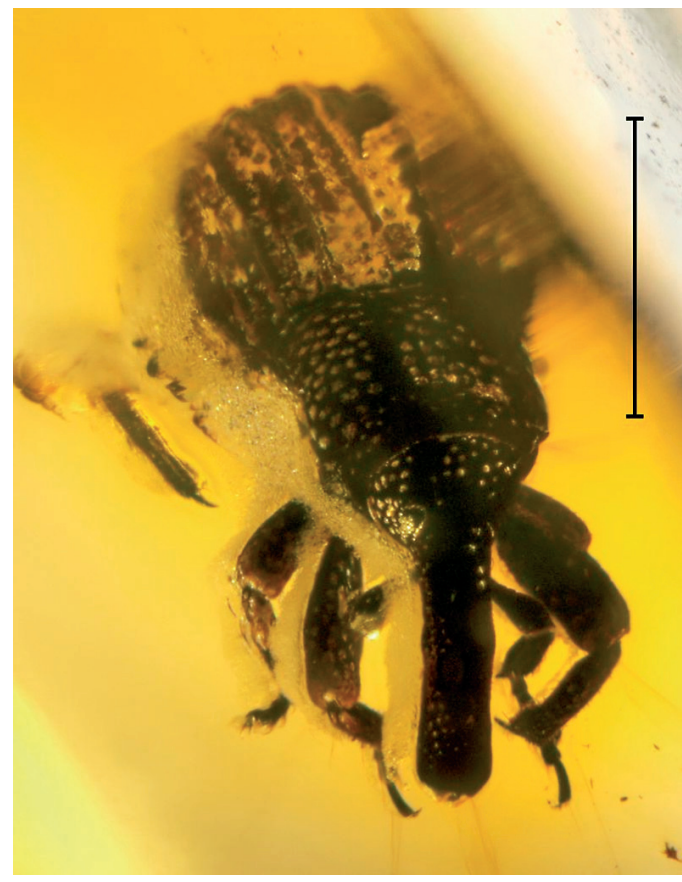

Fig. 3. Frontal view of Palaeodexipeus kirejtshuki sp. n. (holotype). Scale bar $=1 \mathrm{~mm}$.

times longer than wide in apical quarter; greatest width in middle; humeri flattened; punctured striae regular and distinct; punctures rounded and deep; intervals convex, narrow, equal in wide to stria width; odd intervals as carinae.

Thorax. Prosternum largely punctate, without postocular lobes; precoxal part of prosternum weakly elongate, 1.1 times as long as procoxa length; procoxal cavities round, connected; postcoxal part of prosternum 0.7 times as long as procoxa length; mesocoxal cavities rounded, separated; metasternum long, 3.3 times as long as metacoxa length, weakly convex, largely punctate; metepisternum concealed by elytra.

Abdomen. Abdomen weakly convex; ventrites oriented in one plane; $1^{\text {st }}$ and $2^{\text {nd }}$ ventrites elongate and $3^{\text {rd }}$ and $4^{\text {th }}$ ventrites short; $1^{\text {st }}$ ventrite 2.2 times as long as metacoxal length; $2^{\text {nd }}$ ventrite 0.7 times as long as $1^{\text {st }}$ ventrite; $3^{\text {rd }}$ ventrite 0.3 times as long as $2^{\text {nd }}$ ventrite; $4^{\text {th }}$ ventrite equal to $3^{\text {rd }}$ ventrite; $5^{\text {th }}$ ventrite 2.4 times as long as $4^{\text {th }}$ ventrite; pygidium sulcate.

Legs. Legs long; femora weakly clavate, without teeth; profemur length/width ratio 2.6; mesofemur length/width ratio 3.5; metafemur 
length/width ratio 4.3; trochanter conical; tibiae almost straight, flattened, with long uncus and two apical bunches of setae; protibiae length/ width ratio 4.4; metatibia length/width ratio 5.3; tarsi long, with thick light erect setae dorsally; $1^{\text {st }}$ tarsomere conical; $2^{\text {nd }}$ and $3^{\text {rd }}$ tarsomeres not bilobed; $5^{\text {th }}$ tarsomere elongate, with large free claws without teeth, widely separated by lobes; protarsi: $1^{\text {st }}$ tarsomere equal in length and width; $2^{\text {nd }}$ tarsomere 0.9 times longer than wide, 0.9 times as long and equal in width to $1^{\text {st }}$ tarsomere; $3^{\text {rd }}$ tarsomere 1.3 times longer than wide, 1.3 times as long and 0.9 times as wide as $2^{\text {nd }}$ tarsomere; $5^{\text {th }}$ tarsomere 3.0 times longer than wide, 1.8 times as long and 0.8 times as wide as $3^{\text {rd }}$ tarsomere; mesotarsi: $1^{\text {st }}$ tarsomere 0.9 times longer than wide; $2^{\text {nd }}$ tarsomere equal in length and width, equal in length and 0.9 times as wide as $1^{\text {st }}$ tarsomere; $3^{\text {rd }}$ tarsomere 1.3 times longer than wide, 1.3 times as long and equal in width to $2^{\text {nd }}$ tarsomere; $5^{\text {th }}$ tarsomere 4.5 times longer than wide, 1.8 times as long and 0.5 times as wide as $3^{\text {rd }}$ tarsomere; metatarsi: $1^{\text {st }}$ tarsomere 1.1 times longer than wide; $2^{\text {nd }}$ tarsomere equal in length and width, 0.8 times as long and 0.9 times as wide as $1^{\text {st }}$ tarsomere; $3^{\text {rd }}$ tarsomere 1.3 times longer than wide, 1.3 times as long and equal in width to $2^{\text {nd }}$ tarsomere; $5^{\text {th }}$ tarsomere 4.5 times longer than wide, 1.8 times as long and 0.5 times as wide as $3^{\text {rd }}$ tarsomere.

Type locality and type strata. Amber mines located along the Baltic Sea coast and Yantarny Amber quarry near Kaliningrad, Kaliningrad region, Russia, upper Eocene, Prussian Formation.

Etymology. The name is dedicated to Dr. Alexander G. Kirejtshuk (Saint Petersburg, Russia and Paris, France), for his numerous and informative studies on amber beetles.

Remarks. The tibiae with uncus and two apical clusters of setae, ventrites oriented in one plane, elongate first and second ventrites and short third and fourth ventrites, distinct antennal scrobes and geniculate antennae with a compact club indicate that the new species belongs to the family Curculionidae. The new species is placed in the subfamily Dryophthorinae based on the $5^{\text {th }}$ tarsomere having claws widely separated by lobes, mouthparts with prementum withdrawn into oral cavity, antennal club asymmetrical and the first article of the club elongated with the other articles fused. The connected procoxal cavities, metepisternum concealed by the elytra, sulcate pygidium, antennal club weakly obliquely truncate, flat tomentose apical surface, and eyes separated ventrally, suggest placement in the tribe Stromboscerini from the Rovno amber, Madagascar and Oriental region.

\subsection{Description of Dorytomus electrinus sp. $n$.}

Curculioninae Latreille, 1802

Ellescini C. G. Thomson, 1859

Dorytomus Germar, 1817

Dorytomus electrinus sp. n. (Figs. 4-5) Type material. Holotype: no. BA2015/5, female.

Diagnosis. This new species is similar to $D$. luridus (Mannerheim, 1853) from North and West of North America (O'Brien 1970) but differs by the antennae inserted beyond middle of rostrum, mesosternal process convex, smaller body size, naked black body, larger eyes and wide elytra. It is distinguished from $D$. edoughensis Desbrochers, 1875 from Europe and Siberia (Dieckmann 1986) by the naked black body, wide elytra, antennae inserted beyond middle of rostrum, and wider and shorter rostrum.

Description. Female. Body length (without rostrum) $2.4 \mathrm{~mm}$; rostrum length $0.8 \mathrm{~mm}$.

Body black, naked, without scales and setae appearing silvery shiny due to the presence of cavities between specimen and internal surface of its impression.

Head. Head 0.4 times as long as rostrum; rostrum long, narrow, 8.1 times longer than wide at apex, 7.1 times longer than wide in middle, 5.2 times longer than wide at base, 1.3 times as long as pronotum, weakly curved, finely punctate dorsally, densely punctate laterally; antennal scrobes distinct, with the dorsal margin directed toward ventral margin of eye; forehead narrow, narrower than rostrum base width, flattened, finely punctate, without median striae; eyes large, flat, 0.7 times longer than wide, separated ventrally, displaced downwards; vertex weakly flattened, rarely punctate; temples short; antennae inserted beyond middle of rostrum laterally, geniculate, quite long, reaching basal third of pronotum; 


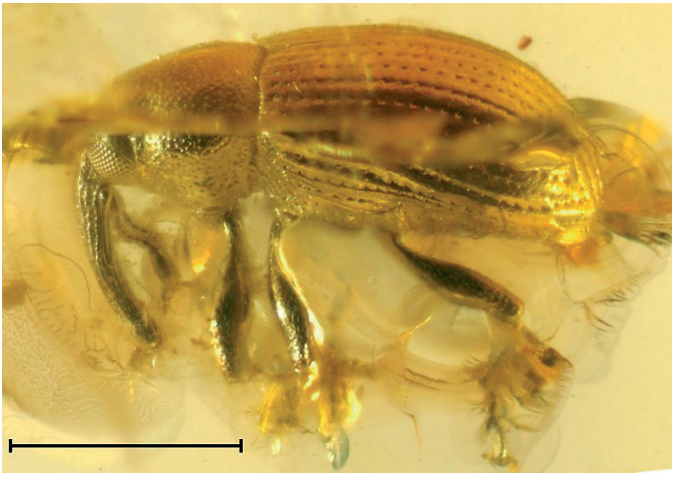

Fig. 4. Lateral (left) view of Dorytomus electrinus sp. $\mathbf{n}$. (holotype). Scale bar $=1 \mathrm{~mm}$.

scape 8.0 times longer than width, distinctly not reaching eye; flagellum with 7 conical desmomeres; $1^{\text {st }}$ desmomere 2.3 times longer than width, 0.3 times as long and almost equal in wide to scape; $2^{\text {nd }}$ desmomere 1.5 times longer than wide, 0.4 times as long and 0.7 times as wide as $1^{\text {st }}$ desmomere; $3^{\text {rd }}-5^{\text {th }}$ desmomeres subequal to $2^{\text {nd }}$ desmomere; $6^{\text {th }}$ desmomere 1.4 times longer than wide, 1.2 times as long and 1.3 times as wide as $5^{\text {th }}$ desmomere; $7^{\text {th }}$ desmomere 1.1 times longer than wide, 1.3 times as long and 1.6 times as wide as $6^{\text {th }}$ desmomere; club compact, 1.7 times longer than wide, 0.4 times as long as funicle, 1.8 times as wide as $7^{\text {th }}$ desmomere.

Pronotum. Pronotum 1.3 times longer than apical width, 0.9 times longer than width in middle and 0.8 longer than width at base; disk weakly narrowed at apex and at base, densely and finely punctate; distance between points larger than diameter of points.

Mesonotum. Scutellum small, trapezoidal.

Elytra. Elytra convex, weakly elongate, 2.5 times as long as pronotum, 1.8 times longer than wide at base, 1.5 times longer than wide in middle, 1.9 times longer than wide in apical quarter; greatest width in middle; humeri weakly flattened; punctured striae regular and distinct; punctures rounded and deep; intervals weakly convex, wide, 2.0-4.0 times as wide as stria width, very finely punctate; $9^{\text {th }}$ stria merges with $10^{\text {th }}$ stria at the level of metacoxae; lateral margins of elytra not arcuately produced laterally at the overlapping point of the apex of metepisternum and filled with setae internally

Thorax. Prosternum densely punctate, with-

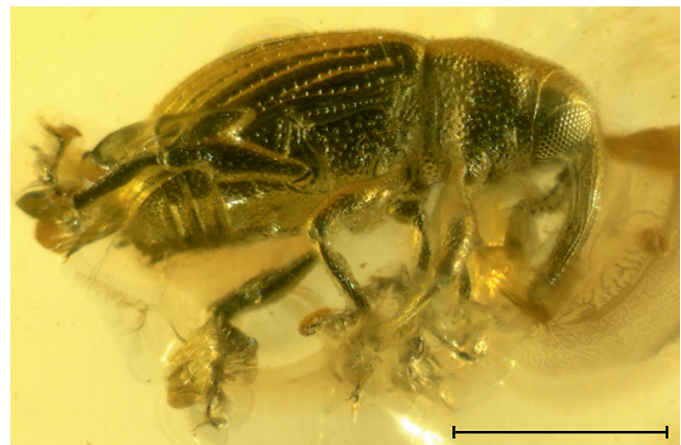

Fig. 5. Lateral (right) view of Dorytomus electrinus sp. n. (holotype). Scale bar $=1 \mathrm{~mm}$.

out postocular lobes; precoxal part of prosternum fairly long, 0.8 times as long as procoxa length, without impression limited on each side of the longitudinal carinae; procoxal cavities round, connected; postcoxal part of prosternum short, 0.2 times as long as procoxa length; mesocoxal cavities rounded, separated; mesosternal process convex; metasternum quite long, 1.2 times as long as metacoxa length, weakly convex, rarely largely punctate; metepisternum narrow, 5.7 times longer than wide, with row of large points.

Abdomen. Abdomen weakly convex, flattened in middle; ventrites oriented in one plane; $1^{\text {st }}$ and $2^{\text {nd }}$ ventrites quite elongate and $3^{\text {rd }}$ and $4^{\text {th }}$ ventrites quite short; $1^{\text {st }}$ ventrite 0.8 times as long as metacoxal length; $2^{\text {nd }}$ ventrite 1.1 times as long as $1^{\text {st }}$ ventrite; $3^{\text {rd }}$ ventrite 0.7 times as long as $2^{\text {nd }}$ ventrite; $4^{\text {th }}$ ventrite 0.9 times as long as $3^{\text {rd }}$ ventrite; $5^{\text {th }}$ ventrite 2.0 times as long as $4^{\text {th }}$ ventrite.

Legs. Legs long; femora weakly clavate, with teeth; profemur length/width ratio 2.4; mesofemur length/width ratio 2.7; metafemur length/width ratio 2.9; trochanter conical; tibiae almost straight, flattened, with small uncus displaced by inner apical angle and two apical bunches of setae; protibiae length/width ratio 4.7; mesotibia length/width ratio 6.0 ; metatibia length/width ratio 5.7; tarsi long, with thick light erect setae dorsally; $1^{\text {st }}$ tarsomere conical; $2^{\text {nd }}$ and $3^{\text {rd }}$ tarsomeres not bilobed; $5^{\text {th }}$ tarsomere elongate, with large free claws without teeth, widely separated by lobes; mesotarsi: $1^{\text {st }}$ tarsomere 1.2 times longer than wide; $2^{\text {nd }}$ tarsomere equal in length and width, 0.8 times as long and equal in width to $1^{\text {st }}$ tarsomere; $3^{\text {rd }}$ tarsomere equal in length and 
width, 1.4 times as long and 1.4 times as wide as $2^{\text {nd }}$ tarsomere; $5^{\text {th }}$ tarsomere 2.7 times longer than wide, 1.2 times as long and 0.4 times as wide as $3^{\text {rd }}$ tarsomere; metatarsi: $1^{\text {st }}$ tarsomere 1.7 times longer than wide; $2^{\text {nd }}$ tarsomere 1.3 times longer than wide, equal in length and 1.3 times as wide as $1^{\text {st }}$ tarsomere; $3^{\text {rd }}$ tarsomere equal in length and width, 1.4 times as long and 1.8 times as wide as $2^{\text {nd }}$ tarsomere; $5^{\text {th }}$ tarsomere 3.7 times longer than wide, 1.6 times as long and 0.4 times as wide as $3^{\text {rd }}$ tarsomere.

Type locality and type strata. Amber mines located along the Baltic Sea coast and Yantarny Amber quarry near Kaliningrad, Kaliningrad region, Russia, upper Eocene, Prussian Formation.

Etymology. The name is formed from the Latin word for "amber" - "electri".

Remarks. The tibiae with uncus and two apical clusters of setae, ventrites oriented in one plane, elongate first and second ventrites and short third and fourth ventrites, distinct antennal scrobes and geniculate antennae with a compact club indicate that the new species belongs to the family Curculionidae. The new species is placed in the subfamily Curculioninae based on the tibiae with small uncus displaced by inner apical angle and $9^{\text {th }}$ stria merging with $10^{\text {th }}$ stria at the level of metacoxae. The antennal scrobes directed toward the eye, precoxal portion of the prosternum elongated, metafemora weakly clavate, not reaching the apex of the abdomen, flagellum 7-articled, claws free, procoxal cavities connected and the tibiae with uncus places the new species in the tribe Ellescini. The femora with teeth and tarsal claws without teeth indicate that the new species belongs to the genus Dorytomus.

\subsection{Description of Scuccinalophus gen. $n$. and a new species}

Entiminae Schoenherr, 1823

Tropiphorini Marseul, 1863

\section{Scuccinalophus gen. $\mathbf{n}$.}

Type species: Scuccinalophus attenboroughi sp. n.

Diagnosis. This new genus is characterized by eyes that are strongly displaced downwards and a small body size $(3.1 \mathrm{~mm})$. The first charac- ter separates it from all other genera of this tribe. There are three extant genera with a small body size $(2.8-4.6 \mathrm{~mm})$. The new genus differs from Beringian Vitaviyus Kissinger, 1974 and Lepidophorus W. Kirby, 1837 from North America (O'Brien \& Wibmer 1982) and Chukchi Peninsula (Korotyaev 1980) by mandibles being with distinct prominent scars at the attachment of the deciduous processes, the scape reaching the distal margin of the eye and the prosternum being without an ocular lobe. From Limalophus Scudder, 1893 from the middle Eocene of USA, it is distinguished by the longer rostrum and pronotum. The new genus is very similar to the European genus Tropiphorus Schoenherr, 1842 but differs by the free tarsal claws, narrower body and longer pronotum.

Etymology. The name is formed from the Latin word for "Amber" - "succinum" and the generic name Alophus.

\section{Scuccinalophus attenboroughi gen. n. et sp. $\mathbf{n}$.} (Fig. 6)

Type material. Holotype: no. BA2015/1, male.

Description. Male. Body length (without rostrum) $3.1 \mathrm{~mm}$; rostrum length $0.5 \mathrm{~mm}$.

Body black, with very dense short, wide, grey-brown contiguous and semierect setiform scales, appearing silvery shiny due to the presence of cavities between specimen and internal surface of its impression.

Head. Rostrum quite short, wide, 0.8 times as long as pronotum, 2.0 times longer than wide in middle, weakly curved, densely punctate, with two sharp transverse carinae, pterygia well developed; scrobes distinct, visible dorsally, directed to upper edge of eyes; forehead wide, convex, densely punctate, without striae; eyes small, 0.6 times longer than wide, barely convex, displaced downwards; vertex weakly flattened, densely punctate; temples very short; mandibles with distinct prominent scars of attachment of deciduous processes; geniculate antennae inserted at apical third of rostrum laterally; antennae long, reaching basal third of pronotum, with rare semierect setae; scape 7.5 times longer than wide, 1.1 times as long as flagellum; desmomeres conical; $1^{\text {st }}$ desmomere 2.0 times longer than wide, 0.2 times as long and 0.8 times as wide as scape; $2^{\text {nd }}$ desmomere 1.1 times longer than wide, 0.5 times 
Fig. 6. Lateral (right) view of Succinalophus attenboroughi sp. $\mathbf{n}$. (holotype). Scale bar $=1 \mathrm{~mm}$.

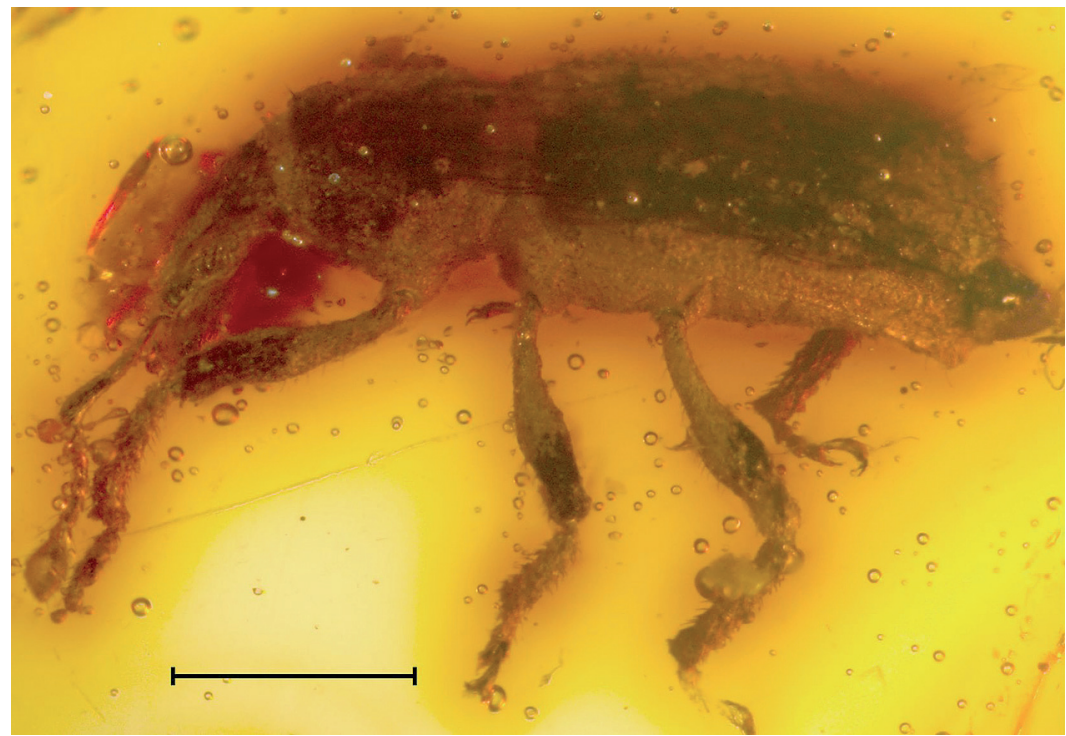

as long and 0.9 times as wide as $1^{\text {st }}$ desmomere; $3^{\text {rd }}$ desmomere 1.1 times longer than wide, 0.9 times as long and 0.9 times as wide as $2^{\text {nd }}$ desmomere; $4^{\text {th }}$ desmomere equal to $3^{\text {rd }}$ desmomere; $5^{\text {th }}$ desmomere equal to $2^{\text {nd }}$ desmomere, 1.1 times as long and 1.1 times as wide as $4^{\text {th }}$ desmomere; $6^{\text {th }}$ desmomere 1.3 times longer than wide, 1.3 times as long and 1.1 times as wide as $5^{\text {th }}$ desmomere; $7^{\text {th }}$ desmomere 1.3 times longer than wide, 1.1 times as long and 1.1 times as long as $6^{\text {th }}$ desmomere; club compact, 1.3 times longer than wide, 0.5 times as long as flagellum, weakly acuminate.

Pronotum. Pronotum bell-shaped, 1.3 times longer than apical width, 1.0 times longer than wide in middle and 1.2 longer than wide at base, 0.8 times as wide as elytral base; greatest width in middle; disk narrowed at apex and at base, densely punctate, without ocular lobes.

Elytra. Elytra weakly elongate and distinctly convex, 2.1 times longer than wide at base, 2.0 times longer than wide in middle, 2.5 times longer than wide in apical quarter, 2.3 times as long as pronotum; greatest width behind middle; humeri completely flattened; punctured striae regular and distinct; punctures elongate-oval, small and dense; intervals flat, wide, 6.0-7.0 times as wide as striae, with middle row of setiform semierect scales.

Thorax. Prosternum densely punctate; precoxal part of prosternum elongate, 1.1 times as long as procoxa length; procoxal cavities round, joined; postcoxal part of prosternum short, 0.5 times as long as procoxa length; mesocoxal cavities rounded, narrowly separated; metasternum long, 1.7 times as long as metacoxa length, convex, punctate; metepisternum narrow, 8.4 times longer than wide.

Abdomen. Abdomen flattened; ventrites oriented in one plane; $1^{\text {st }}$ and $2^{\text {nd }}$ ventrites elongate, subequal in length; $1^{\text {st }}$ ventrite 1.5 times as long as metacoxa; $3^{\text {rd }}$ and $4^{\text {th }}$ ventrites short, equal in length; $3^{\text {rd }}$ ventrite 0.4 times as long as $2^{\text {nd }}$ ventrite; $5^{\text {th }}$ ventrite 1.6 times as long as $4^{\text {th }}$ ventrite.

Legs. Legs long; femora and tibiae with dense broad scales and rarely semierect setae; femora weakly clavate, without teeth; profemur length/width ratio 3.8; mesofemur length/width ratio 4.0 ; metafemur length/width ratio 3.6; trochanter conical; tibiae almost straight, weakly flattened, widened at apices, with mucro and apical dark setose fringe, without uncus; metatibial corbels open; protibia length/width ratio 4.3; mesotibia length/width ratio 4.5 ; metatibia length/width ratio 4.6; tarsi long, with thick light erect setae dorsally; $1^{\text {st }}$ and $2^{\text {nd }}$ tarsomeres triangular; $3^{\text {rd }}$ tarsomere bilobed; $5^{\text {th }}$ tarsomere elongate; claws large, free, without teeth; protarsi: $1^{\text {st }}$ tarsomere 1.3 times longer than wide; $2^{\text {nd }}$ tarsomere 0.9 times longer than wide, 0.6 times as long and 0.9 times as wide as $1^{\text {st }}$ tarsomere; $3^{\text {rd }}$ tarsomere equal in length and width, 1.5 times as long and 1.3 times as wide as $2^{\text {nd }}$ tarsomere; $5^{\text {th }}$ tarso- 
mere 2.8 times longer than wide, 1.6 times as long and 0.6 times as wide as $3^{\text {rd }}$ tarsomere; mesotarsi: $1^{\text {st }}$ tarsomere 1.2 times longer than wide; $2^{\text {nd }}$ tarsomere 0.8 times longer than wide, 0.7 times as long and 1.1 times as wide as $1^{\text {st }}$ tarsomere; $3^{\text {rd }}$ tarsomere equal in length and width, 1.6 times as long and 1.2 times as wide as $2^{\text {nd }}$ tarsomere; $5^{\text {th }}$ tarsomere 3.5 times longer than wide, 1.8 times as long and 0.5 times as wide as $3^{\text {rd }}$ tarsomere; metatarsi: $2^{\text {nd }}$ tarsomere 0.6 times as long as wide as $1^{\text {st }}$ tarsomere; $3^{\text {rd }}$ tarsomere 1.6 times as long as $2^{\text {nd }}$ tarsomere; $5^{\text {th }}$ tarsomere 1.5 times as long as $3^{\text {rd }}$ tarsomere.

Type locality and type strata. Amber mines located along the Baltic Sea coast and Yantarny Amber quarry near Kaliningrad, Kaliningrad region, Russia, upper Eocene, Prussian Formation.

Etymology. The name is dedicated to Sir David F. Attenborough (London, UK), for his great contribution of popularizing natural history.

Remarks. The new genus and species belong to the family Curculionidae based on the following characters: ventrites oriented in one plane, elongate first and second ventrites and short third and fourth ventrites, distinct antennal scrobes and geniculate antennae with a compact club. The mandibles with prominent scars of attachment of deciduous processes, rostrum quite short and tibiae without uncus, suggest placement in the subfamily Entiminae. The eyes displaced downwards, rostrum 2.0 times longer than wide, tarsal claws free and lateral antennal scrobes indicate that the new genus belongs to the tribe Tropiphorini.

\section{Discussion}

Representing the family Belidae, the subfamily Oxycoryninae dates back to the early Cretaceous of Spain (Gratshev \& Legalov 2014). Ten tribes (Afrocorynini, Aglycyderini, Allocorynini, Alloxycorynini, Archicorynini, Distenorrhinoidini, Metrioxenini, Oxycorynini, Oxycraspedini and Palaeorhopalotriini) are known (Legalov 2009, 2013a; Anderson \& Marvaldi 2013). The tribes Distenorrhinoidini (Berriasian-Barremian of Montsec) and Palaeorhopalotriini (upper Eocene of Ale`s-Monteils) are extinct (Legalov 2009, 2013a). One fossil representative of the genus was described from the Miocene Dominican amber (Poinar \& Legalov 2014b). Several extinct species of the tribe Metrioxenini, widespread in the Oriental region, are know from the Baltic amber (Legalov 2012a, 2012b, 2013a). The tribe Oxycraspedini with the genus Oxycraspedus from Chile and Argentina differs from the South American tribe Oxycorynini by the separated procoxal cavities. The specimens of Oxycraspedini can be identified as representatives of Metrioxenini by the head behind eyes being without a groove and the pronotum being without discal carinae. Three extant species of Oxycraspedus from Chile and Argentina develop in female strobili of Araucaria araucana (Kuschel 1995b, 2001, Ferrer et al. 2007). The Baltic amber species developed possibly also in Araucaria.

Twenty fossil species of the subfamily Dryophthorinae are known (Legalov 2015). The first records of this subfamily are based on a genus of the tribe Strombocerini in the Rovno amber (Nazarenko \& Perkovsky 2009) and undescribed species of the tribe Orthognathini (Schlee 1990). Dryophthorinae are found in the terminal Eocene of the Florissant beds (Scudder 1893) and in the Miocene Dominican amber (Davis \& Engel 2006, 2009; Poinar \& Legalov 2014a, 2015b). Palaeodexipeus kirejtshuki gen. n. et sp. n. is the first record of the tribe Strombocerini, and the first described representative of the subfamily Dryophthorinae in the Baltic amber.

The oldest Curculioninae from the tribe Curculionini are described from the Paleocene of France (Piton 1940), because the earlier representative described in this subfamily (Poinar 2009) belongs to another family (Legalov \& Poinar 2015). Members of this subfamily are abundant in the terminal Eocene of Florissant (Scudder 1893; Legalov 2015) and Miocene Dominican amber (Poinar \& Legalov 2015a). Species of the genera Succinostyphlus Kuska, 1996, Dorytomus Germar, 1817 and Pachytychius Jekel, 1861 from the tribe Ellesini have been described from the Baltic amber (Kuska 1996, Legalov in press).

The tribe Tropiphorini is distributed worldwide. The first finds are in the middle Eocene Green River (Scudder 1893). Some species are described from the terminal Eocene of Florissant (Scudder 1893; Wickham 1911) and Oligocene of France (Zherikhin 1992). Scuccinalophus 
attenboroughi gen. n. et sp. n. is the first finding and the first described representative of the tribe Tropiphorini in the amber.

The insect fauna of the Baltic amber is quite well known (Bachofen-Echt 1949; Larsson 1978; Poinar 1992; Weitschat \& Wichard 2010). Ninety-three species from six families of weevils (Nemonychidae - 1, Anthribidae - 11, Belidae 5, Rhynchitidae -8 , Brentidae - 10, Curculionidae -37 and Scolytidae - 21) have been described from the Baltic amber (Germar 1813; Motschulsky 1857; Foerster 1891; Hagedorn 1906, 1907; Wagner 1924; Hustache 1942; Schedl 1947; Ulke 1947; Voss 1953; Zherikhin 1971; Voss 1972; Wanat \& Borowiec 1986; Kuska 1992; Gratshev \& Zherikhin 1995; Kuska 1996; Rheinheimer 2007; Riedel 2010; Yunakov \& Kirejtshuk 2011; Riedel et al. 2012; Legalov 2012a, 2012b, 2012c, 2013a, 2015, in press). The here presented new fossil records provide a still wider base of the weevil fauna from this amber source.

Acknowledgements. The author thanks O. Jaeger (Germany: Dresden), K.-D. Klass (Germany: Dresden), B. A. Korotyaev (Russia: St.-Petersburg), and Ch. W. O'Brien (USA: Green Valley) for the opportunity to study comparative material, Dr. George O. Poinar, Jr (USA: Corvallis) for improving the manuscript, and anonymous reviewers for their comments. The study was partially supported by the Federal Fundamental Scientific Research Program for 2013-2020, project no. VI.51.1.7 and the Russian Foundation for Basic Research, project no. 15-04-02971.

\section{References}

Alonso-Zarazaga, M. A. \& Lyal, C. H. C. 1999: A world catalogue of families and genera Curculionoidea (Insecta: Coleoptera) (excepting Scolytidae and Platypodidae). - Barcelona, Entomopraxis. 316 pp.

Anderson, R. S. 2002: Curculionidae: 722-815. - In: Arnett, R. H., Jr., Thomas, M. C., Skelley, P. E. \& Frank, J. H. (eds), American beetles. Polyphaga: Scarabaeoidea through Curculionoidea. 2. Boca Raton-LondonNew York-Washington. CRC Press. 861 pp.

Anderson, R. S. \& Marvaldi, A. E. 2013: Finding unexpected beetles in odd places: Archicorynus kuscheli Anderson and Marvaldi, a new genus and species representing a new tribe, Archicorynini, of Oxycoryninae (Coleoptera: Belidae) from Nicaragua. - Coleopterists Bulletin 67(2): 61-71.

Bachofen-Echt, A. 1949: Der Berstein und seine Einschlüsse. - Wien, Springer-Verlag. 204 pp. [In German.]
Bouchard, P., Bousquet, Y., Davies, A. E., Alonso-Zarazaga, M. A., Lawrence, J. F., Lyal, C. H. C., Newton, A. F., Reid, C. A. M., Schmitt, M., Ślipiński, S. A. \& Smith, A. B. T. 2011: Family group names in Coleoptera (Insecta). - Zookeys 88: 1-972.

Davis, S. R. \& Engel, M. S. 2006: Dryophthorine weevils in Dominican amber (Coleoptera: Curculionidae). Transactions of the Kansas Academy of Science 109(3-4): 191-198.

Davis, S. R. \& Engel, M. S. 2009: An orthognathine weevil of the genus Mesocordylus in Dominican amber. Beiträge zur Entomologie 59: 233-238.

Dieckmann, L. 1986: Beiträge zur Insektenfauna der DDR: Erirhinae. - Beiträge zur Entomologie 36(1): 119-181. [In German.]

Ferrer, M. S., Marvaldi, A. E. \& Tognelli, M.F. 2007: First records of three species of Oxycraspedus Kuschel (Coleóptera: Belidae) in Argentina and use of a predictive model to compare their potential distribution with the range of their host-plant, Araucaria araucana. Revista Chilena de Historia Natural 80: 327-333.

Foerster, B. 1891: Die Insekten des "Plattigen Steinmergels" von Brunstatt. — Abhandlungen der Geologischen Specialkarte von Elsass-Lotheringen 3(5): 333-594, XI-XVI. [In German.]

Germar, E. F. 1813: Insekten in Bernstein eingeschlossen, beschrieben aus dem academischen Mineralien Cabinet Halle. - Magazin der Entomologie 1: 11-18. [In German.]

Gratshev, V. G. \& Legalov, A. A. 2011: New Mesozoic Ithyceridae beetles (Coleoptera). — Paleontological Journal 45(1): 76-81.

Gratshev, V. G. \& Legalov, A. A. 2014: The Mesozoic stage of evolution of the family Nemonychidae (Coleoptera, Curculionoidea). - Paleontological Journal 48(8): 851-944.

Gratshev, V. G. \& Zherikhin, V. V. 1995: A new anthribid genus from the Baltic amber (Insecta: Coleoptera: Anthribidae). - Mitteilungen aus dem Geologisch-Paläontologischen Institut der Universität Hamburg 78: 149-157.

Grigjalis, A. A., Baltakis, V. V. \& Katinas,V. 1971: Stratigraphy of Paleogene deposits in the Baltics. - Izvestija Akademii Nauk SSSR. Serija Geologicheskaja 3: 107-116. [In Russian.]

Hagedorn, M. 1906: Borkenkäfer des baltischen Bersteins. - Schriften Physikalisch-Ökonomischen Gesellschaft Königsberg Prussia 47: 115-121. [In German.]

Hagedorn, M. 1907: Kopalborkenkäfer. — Verhandlungen des Vereins für naturwissenschaftliche Unterhaltungen Hamburg 13: 109-112. [In German.]

Hustache, A. 1942: Un curculionide de l'ambre de la Baltique. - Bulletin Mensuel de la Société Linnéenne de Lyon 11: 108-109. [In French.]

Klimaszewski, J. \& Watt, J. C. 1997: Coleoptera: familygroup review and keys to identification. - Fauna of New Zealand 37: 1-199.

Korotyaev, B. A. 1980: Material on the weevil fauna (Coleoptera, Curculionidae) of the northeastern USSR. - 
Studies on the entomofauna of the northeastern USSR. Vladivostok: 23-50. [In Russian.]

Kuschel, G. 2001: La fauna curculiónica (Coleóptera: Curculionoidea) de la Araucaria araucana. - Revista Chilena de Entomología 27: 41-51. [In Spanish.]

Kuschel, G. 1995a: A phylogenetic classification of Curculionoidea to families and subfamilies. - Memoir of the Entomological Society of Washington 14: 5-33.

Kuschel, G. 1995b: Oxycorynus missionis spec. nov. from NE Argentina, with key to the South American species of Oxycoryninae (Coleoptera, Belidae). - Acta Zoologica Lilloana 43(1): 45-48.

Kuska, A. 1992: Three new species of beetles (Coleoptera: Cantharidae, Anobiidae, Curculionidae) from the Baltic amber. - Annals of the Upper Silesian Museum in Bytom - Entomology 3: 107-113.

Kuska, A. 1996: New beetle species (Coleoptera, Cantharidae, Curculionidae) from the Baltic amber. - Prace Muzeum Ziemi 44: 13-23.

Larsson, S. G. 1978: Baltic amber - a palaeobiological study. - Entomonograph 1:1-192.

Legalov, A. A. 2009: Annotated checklist of fossil and recent species of the family Belidae (Coleoptera) from the world fauna. - Amurskii Zoologicheskii Zhurnal 1(4): 296-324.

Legalov, A. A. 2011: First record of Anthribid beetles from the Jurassic of Kazakhstan (Coleoptera: Anthribidae). — Paleontological Journal 45(6): 629-633.

Legalov, A. A. 2012a: A new weevil genus of the tribe Metrioxenini (Coleoptera: Belidae) in Eocene Baltic amber. - Historical Biology 24(2): 213-217.

Legalov, A. A. 2012b: New Curculionoid beetles (Coleoptera: Curculionoidea) from the Baltic amber. - Paleontological Journal 46(3): 262-272.

Legalov, A. A. 2012c: New and little known Apioninae (Coleoptera, Brentidae) in Eocene Baltic amber. Evraziatskii entomologicheskii Zhurnal 11(3): 219222.

Legalov, A. A. 2012d. Fossil history of Mesozoic weevils (Coleoptera: Curculionoidea). - Insect Science 19(6): 683-698.

Legalov, A. A. 2013a: New and little known weevils (Coleoptera: Curculionoidea) from the Paleogene and $\mathrm{Ne}$ ogene. - Historical Biology 25(1): 59-80.

Legalov, A. A. 2013b: Review of the family Anthribidae (Coleoptera) from the Jurassic of Karatau: subfamily Protoscelinae. Genus Protoscelis Medvedev. - Paleontological Journal 47(3): 292-302.

Legalov, A. A. 2015: Fossil Mesozoic and Cenozoic weevils (Coleoptera, Obrienioidea, Curculionoidea). Paleontological Journal 49(13): 1442-1513.

Legalov, A. A.: New weevils (Coleoptera: Curculionidae) in Baltic amber. - Paleontological Journal 50. (In Press.)

Legalov, A. A. \& Poinar, G. Jr. 2015: New tribes of the superfamily Curculionoidea (Coleoptera) in Burmese amber. - Historical Biology 27(5): 558-564.

Motschulsky, V. 1857: Voyages. Lettres de M. de Motschulsky à M. Ménétriés. N ${ }^{\circ} 4$. —Études Entomologiques 5: 21-38. [In French.]
Nazarenko, V. Y. \& Perkovsky E. E. 2009: A new genus and species of Dryophthorid weevils (Coleoptera, Dryophthoridae: Stromboscerinae) from the Rovno amber. - Paleontological Journal 43(9): 1097-1100.

O'Brien, Ch. W. 1970: A taxanomic revision of the weevil genus Dorytomus (Coleoptera: Curculionidae) in North America. - University of California publications in Entomology 60: 1-80.

O’Brien, Ch. W. \& Wibmer, C. J. 1982: Annotated checklist of the weevils (Curculionidae sensu latu) of North America, Central America and the West Indies (Coleoptera: Curculionoidea). - Memoirs of the American Entomological Institute 34: 1-382.

Piton, L. 1940: Paléontologie du gisement Éocène de Menat (Puy-de-Dôme) (Flore et faune). — Clermont-Ferrand: Imprimeries Paul Vallier. 303 pp. [In French.]

Poinar, G. Jr. 1992: Life in Amber. — Stanford University Press. 350 pp.

Poinar, G. Jr., 2009. Palaeocryptorhynchus burmanus, a new genus and species of Early Cretaceous weevils (Coleoptera: Curculionidae) in Burmese amber. Cretaceous Research 30: 587-591.

Poinar, G. Jr. \& Legalov, A. A. 2014a: Bicalcasura maculata n. gen., n. sp. (Curculionoidea: Dryopthtoridae) with a list of weevils described from Dominican amber. - Historical Biology 26(4): 449-453.

Poinar, G. Jr. \& Legalov, A. A. 2014b: Pleurambus strongylus n. gen., n. sp. (Coleoptera: Belidae) in Dominican amber. - Historical Biology 26(5): 670-674.

Poinar, G. Jr. \& Legalov, A. A. 2015a: New Curculioninae (Coleoptera: Curculionidae) in Dominican amber. Palaeontologia Electronica 18(1)13A: 1-15.

Poinar, G. Jr. \& Legalov, A. A. 2015b: New species of the genera Dryophthorus Germ. and Stenommatus Woll. (Coleoptera: Dryophthoridae) in Dominican amber. - Historical Biology 27(5): 508-513.

Rheinheimer, J. 2007: Neue fossile Rüsselkäfer (Coleoptera: Curculionidae) aus dem Eozän des Baltischen Bernsteins und der Grube Messel bei Darmstadt. Staatliches Museum für Naturkunde B(365): 1-24. [In German.]

Riedel, A. 2010: A new tribe, genus and species of Nemonychidae from Baltic amber (Coleoptera: Curculionoidea: Nemonychidae: Cimberidinae). — Insect Systematics \& Evolution 41: 29-38.

Riedel, A., dos Santos Rolo, T., Cecilia, A, \& van de Kamp, T. 2012: Sayrevilleinae Legalov, a newly recognised subfamily of fossil weevils (Coleoptera, Curculionoidea, Attelabidae) and the use of synchrotron microtomography to examine inclusions in amber. - Zoological Journal of the Linnean Society 165(4): 773-794.

Schedl, K. 1947: Die Borkenkäfer des baltischen Bernsteins. - Zentralblatt fuer das Gesamtgebiet der Entomologie 2(1): 12-45. [In German.]

Schlee, D. 1990: Das Bernslein-Kabinett. — Stuttgarter Beiträge zur Naturkunde C(28): 1-100. [In German.]

Schubert, K. 1961: Neue Untersuchungen über Bau und Leben der Bernsteinkiefern (Pinus succinifera 
(Conw.) emend.). - Beihefte Geologischen Jahrbuch 45: 1-149. [In German.]

Scudder, S. H. 1893: Rhynchophorus Coleoptera of the United States. - Monographs of the United States Geological Survey 21: 1-206.

Ulke, T. 1947: A new genus and species of Curculionidae (Coleoptera) in Baltic amber. - Notulae Naturae. Philadelphia 193: 1-5.

Voss, E. 1953: Einige Rhynchophoren der Bernsteinfauna (Col.). - Mitteilungen des geologischen Staatsinstitutes von Hamburg 22: 119-140. [In German.]

Voss, E. 1972: Einige Rüsselkäfer der Tertiärzeit aus Baltischem Bernstein (Coleoptera, Curculionoidea). Steenstrupia 2: 167-181. [In German.]

Wagner, H. 1924: Ein neues Apion aus dem baltischen Bernstein (Coleoptera, Curculionidae). - Deutsche Entomologische Zeitschrift: 134-136. [In German.]

Wanat, M. \& Borovec, L. 1986: New genus of weevil (Coleoptera, Curculionidae) from Baltic amber. - Polskie pismo entomologiczne 56: 243-247.

Weitschat, W. \& Wichard, W. 2010: Baltic amber: 80-115. — In: Penney, D. (ed.), Biodiversity of fossils in am- ber from the major world deposits. Siri Scientific Press, Manchester. 304 pp.

Wickham, H. F. 1911: Fossil Coleoptera from Florissant, with descriptions of several new species. - Bulletin of the American Museum of Natural History 30: 53 69.

Yunakov, N. N. \& Kirejtshuk, A. G. 2011: New genus and species of broad-nosed weevils from Baltic amber and notes on fossils of the subfamily Entiminae (Coleoptera, Curculionidae). — ZooKeys 160: 73-96.

Zherikhin, V. V. 1971: On weevils (Insecta, Coleoptera) from the Baltic Amber. - Trudy Paleontologicheskogo Instituta, Moscow 130: 197-209. [In Russian.]

Zherikhin, V. V. 1992: Tertiary weevils (Insecta, Coleoptera: Curculionoidea), identified from the collections of the Senckenberg Museum, Senckenberg. - Lethaea $72: 169-178$

Zherikhin, V. V. \& Egorov, A. B. 1991: Weevils (Coleoptera, Curculionidae) from the Russian Far East: Review of subfamilies with description of new taxa. Vladivostok. 164 pp. [In Russian.] 